\title{
Leadership of Society-Based Education in Improving the Acceleration of Educational Organization in the Disruption Era
}

\author{
Gres Jekstman Kaipatty $^{1}$, Ari Tri Soegito ${ }^{2}$, Wahyono ${ }^{3}$, Kardoyo ${ }^{4}$ \\ ${ }^{1,2,3,4}$ Graduate School, Universitas Negeri Semarang, Indonesia \\ Corresponding email: gkaipatty@yahoo.com
}

\begin{abstract}
In improving the acceleration of educational organization in the disruption era, leadership played very important role, especially by observing education as one of the fundamental needs of human's life. The purpose of this paper is to analyze how leadership works in creating changes through educational organization in the disruption era and in developing educational organizations in the disruption era. The method used in this study was qualitative approach. Data were obtained through interviews, observations, and document studies. The finding showed that it was leadership of society-based education in essence that was considered very important in constructing, improving, and developing the growth of educational organization. In this case, education functions as a social system as well as an integral part of the larger social system in society. Education and society have very close relationship in supporting the achievement of goals or the fulfillment of society needs, especially the needs of education. Several conclusions can be drawn. The relationship between educational leadership and the society in this disruption era attempts to (1) advance the quality of learning and education growth; (2) strengthen the objectives as well as improve the quality of life in the society; and (3) encourage people to connect with education.
\end{abstract}

Key words: leadership, society-based education, organization, disruption

\section{Introduction}

An organization in this disruption era cannot be separated from the fact that in this world there are always changes. The changes itself cover all aspects of life in both individual and organizational levels. It is interesting to note that despite the changes in all aspects of life, changes in one area must have direct or indirect effects on the other areas of life. Educational leadership should be sensitive to the changes that occur outside of the organization one leading - whether she/he is able to calculate and accommodate the effects of those changes. Educational leadership should have the skills to make changes within the organization in order to improve the organization and achieve the goals that have set. In improving the acceleration of an educational organization in the disruption era disruption, hence, the leadership has a very important and strategic role, especially by viewing education as one of the basic needs of human life.

\section{Method}

The method used was a qualitative approach. The data sources were taken from interviews, observations, and document studies. The objectives of this study are to analyze and explain how community-based leadership works in creating accelerated changes in educational organizations in the era of disruption and in developing educational organization in the disruption era.

\section{Result and Discussion}

The dynamics of the disruption era in the $21^{\text {st }}$ century views changes from not only certain issues but also their benefits and effects. Pangestu (2015) argues that Indonesia in the $21^{\text {st }}$ century faces "a new normality" or changing conditions. This new normality is characterized by a global economic system that has been increasingly integrated with national and local economic activities. This integration is supported by innovation and efficiency of information technology, communications, and transportation enabling the establishment of a global distribution network. Therefore, development is no longer purely based on manufacturing or production capability, but it has moved towards innovation of production methods, value-added product innovation, and distribution network innovation.

The opinions related to the impact of the changes indicate that the issue of leadership in education also needs to be viewed because leadership means a leader in influencing the behaviors of subordinates to cooperate and work 
productively to achieve the goals of an organization. Tan (2013) states in educational leadership, it is found that there are four factors determining educational leadership: school system, policy, human resources, and solidarity. The relationship between leadership behaviors and employee outcomes attempts to identify specific leadership behaviors and examine the relationships between behavioral use and performance, job satisfaction and organizational commitment of employees. According to Cole \& Latham (1997) leadership will be effective if it is built through leaders who act as teachers teaching effective discipline over the actions of his subordinates. Kelloway, et al. (2006) suggest leadership transformation is very influential in terms of role and feedback on learning orientation. Horwitz (1999) states the expected learning orientation can be realized if there is strong motivation from the leaders in policy formulation.

The need for management in accelerating the change of educational organization in this disruption era is prompted by development and changes that occur in the globalization society, regarding the fact that phrase of everything must change. One that does not change is the change itself. This challenge is actually derived from two factors that influence each other, both from external factors and internal factors which can be divided into three points. The world of education is required to be able to maintain the results of educational development that has been achieved, to anticipate the era of globalization, and to prepare competent human resources in order to compete in the global job market. McDonald, et al. (2007) state that national education system is required to make changes and adjustments. Therefore, it can realize democratic education processes, pay attention to diversity, and encourage community participation. Mackinnon (2003) states in this context, education is one way in which people want to improve themselves and to reach new opportunities. he dynamic influence of the context is very influential for the development of education.

Based on the explanation above, related to the leadership of education, the following describes the leadership of education in relation to community-based education, especially in organizational change. The community itself is a collection of populations living in an adjacent territory, being integrated through common experience, having a number of basic service situations, being aware of its local unity and being capable of acting in its capacity. Suharto (2012: 74) emphasizes that community is interpreted as a group of people who inhabit a particular region with all the ties and norms in it, understand the existing potential within the region and then attempt to build its territory with its potential. Elson (2015) also emphasizes that leadership in educational community is linked to a contextual understanding of school leadership practices taking into account the cultural, institutional and political dimensions of educational organizations and their environment.

The purpose of leadership is to manage quality education. The recent developments have shown the acceleration and expectations are placed at higher levels of education to develop socially responsible citizens and to create graduates who will be able to resolve increasingly complex issues. There are three important points in the acceleration of education level in the community-based leadership, they are: (a) contributing to mission services and educational institutions; (b) developing student capacity for, and against, social responsibility; and (c) adding the value to community-centered learning. Juliet (2011) reveals a good educational leadership in relation to community-based education is one of the keys to be able to create a good relationship between education and society effectively because it has to pay attention to what happens to students in the school and what parents think about education.

Educational leadership is required to continuously foster and improve good relationships between schools and communities in order to realize effective and efficient schools. This harmonious relationship constitutes (a) mutual understanding between education, parents, community, and other institutions in the society, including employment. (b) mutual assistance between education and society because they know the benefits, meanings, and importance of each role. (c) close cooperation between education and the various parties within the community. Through this relationship, the purpose of education and community relations is expected to be achieved. It can be said the education process is implemented productively, effectively, and efficiently. 
Hidayatun (2017) states that community-based education makes changes to education and the needs for education. As a result, they prefer educational institutions for more selective considerations.

Creating a bond between education and society by adopting a community culture in a formal educational setting will help the education acquire a particular position. After the implementation, the education has increased significantly. The analysis of these facts resulted in a conclusion that the implementation of culture enhances interest from the society, emotional attachment, and loyalty to schools. The educational leadership is inseparable from the role of society. The ideal education is education that lives from and for society. Community-based education is a form of education. Tilaar (2000) emphasizes that education will be alienated from the context of its objectives when the participation of the community is ignored as education is unable to respond to the real needs and cultures. The education separated from the society and culture is the one that has no responsibility. Community-based education is a manifestation of democratization and decentralization of education.

The explanation of several opinions above emphasizes that community-based education leadership can bring and save an organization to achieve its stated goals. This era of disruption implies that everyone is a leader who will be asked for his/her accountability. The leadership starts with a vision and tasks to prepare for new leaders, understand change, foster a sense of participation, and create a learning culture. This era of disruption also demands the leaders to be able to create harmony within an organization, build integrity, have firmness, become communicator, build negotiation as well as friendship, and be open-minded.

Developing an organization in the era of disruption emphasizes that leadership is the ability to influence the activities of a group towards the achievement of the goals set. Sutisna (1982) states it can also be formulated as a process affecting the activities of a person or group in attempt to achieve goals in certain situations. Yukl (2005) concludes several definitions of leadership taken from the experts' ideas. Hemphill \& Coons (1957) argue that leadership is an individual behavior that directs group activities to achieve common goals.
Katz \& Kahn (1978) define leadership as an improvement of the influence that exceeds mechanical adherence towards routine organizational commands. Burns (1978) asserts that leadership is conducted when one mobilizes institutional, political, psychological, and other resources to awaken the motivation of his followers. Smircich \& Morgan (198) further state that leadership is underlying in the process when one or more individuals succeed in shaping and determining the lives of others.

It can be concluded that leadership is the ability to influence others, subordinates or groups, the ability to direct the behavior of subordinates or groups. Leadership means the ability or special skills in the field desired by the group to achieve organizational goals. Developing educational organizations in this era of disruption is also based on several models of educational leadership. There are six models which consist of formal model, collegial model, political model, subjective model, ambiguity model, and cultural model. Models vary widely in terms of their concept and operation. According to Bush (2006), the characteristics of educational leadership in developing educational organizations in the era of disruption embrace three main characteristics. (1) Leadership is normative. (2) Leadership is selective. (3) observative. Normative leadership refers to the criteria needed to meet the needs of educational institutions by appropriate people, especially in terms of the commitment and ability. Observative leadership refers to leader's activities based on the data and developing a grounded concept or using a particular theory to choose the right concept to measure the ability and performance of people in the educational institution.

In this era of disruption, leaders can be interpreted as the main activator in an educational institution that becomes the main holder of the organization's path - people who have authority in decision-making and influence others to perform certain tasks. In addition, a leader has the authority, influence, power and key responsibility holders for all activities undertaken by their subordinates. In educational institutions, leaders are people who have a leading position in running the wheel of a system. Based on the task, hence, the main function of leaders in this era of disruption according to Salahudin (2011: 196) is to run the leadership properly and correctly with 
the basis of manager or main controller. Leaders are those who perform the main functions and main concepts as well as formulate the vision, mission, objectives of educational institutions so that from the planning to accountability, they are directed to the goals that have been set. Motivators are those who encourages and gives full support to his subordinates to work optimally. Decision makers refer to those who will affect the development and the progress of education and the welfare of educational behavior. Performance appraisers are those whose work will be rewarded by the subordinates. Dynamicators and catalyst of the institution are those who promotes and controls the circumstances that will affect the progress or deterioration of the educational institution. Stabilizers are those who have the strongest capability in maintaining the existence of educational institutions. Supervisors, then, refer to those who guide, train, educate supervise, assesse and provide an example of the best work for all educators they lead.

\section{Conclusion}

From the explanation described above, it can be concluded that leadership of communitybased education in improving the acceleration of educational organizations in the era of disruption can be seen from two main points. First, it is how community-based leadership works in creating changes in educational organizations in the era of disruption. Second, it is how leadership works in developing educational organizations in the era of disruption. Those two main points suggest that there is a relationship between educational leadership and the community in the era of disruption that aims to (a) advance the quality of learning, and the growth of education; (b) strengthen the objectives and improve the quality of life of the community; (c) encourage people to connect with education; (d) understand changes with a sense of participation in creating an organizational culture, and; (e) be open-minded in creating harmony within an organization through attitudes built on the basis of integrity, steadfastness, communicators, and negotiation.

\section{References}

Burns, James MacGregor. (1978). Leadership. New York: Harpen \& Row.
Bush. Tony. (2006). Theories of Educational Leadership and Management. London: SAGE Publications.

Cheng Yong Tan. (2013). "Educational leadership in Singapore Tight coupling, sustainability, scalability, and succession". Journal of Educational Administration. 51 (3), 320-340.

Cole D. Nina and Latham P. Gary. (1997). Effects of Training in Procedural Justice on Perceptions of Disciplinary Fairness by Unionized Employees and Disciplinary Subject Matter Expert. Journal of Applied Psychology. 82 (5), 699-705.

Elson Szeto, Theodore Tai Hoi Lee, Philip Hallinger. 2015. A systematic review of research on educational leadership in Hong Kong. Journal of Educational Administration. 53 (4), 534-553.

Hemphill, J.K., \& Coons, A.E. (1956). Development of the leader behavior: Its Description and Measurement. Columbus: Bereau of Business Research, Ohio State University.

Hidayatun. (2017). Creating Community Bond through Cultural Branding to Maintain Community-Based Schools. The Journal of Educational Development. 5 (3), 393-403.

Horwitz M. Frank. (1999). The emergence of strategic training and development: the current state of play. Journal of European Industrial Training. 23 (4), 180-190.

Juliet Millican, Tom Bourner. (2011). Student community engagement and the changing role and context of higher education. Journal Education. 53 (2/3), 89-99.

Katz, D \& Kahn, R. L. (1978). The Social Psychology of Organizations $(2$ ed). New York: John Wiley.

Kelloway, Kevin E, Barling, Julian and Helleur, Jane. (2000). Enhancing transformational leandership: the roles of training and feedback, Leandership \& Organization Development. Journal. 21 (3), 145-149.

MacKinnon, Allan. (2013). Post-Secondary Education Development in South East Asia: A Model for Curriculum Development in Continuing Education. Journal of Educational Research. 58 (4).

McDonald, Ria; Van Der Horst, Halen. (2007). Curriculum Aligment, Globalization, And Quality Assurance in South Africa, Higher 
Education. Journal of Curriculum Studies. 39 (1).

McNeese-Smith, Dona. (1996). Increasing Employee Productivity, Job Satisfaction, and Organizational Commitment. Journal Hospital and Health Services Administration. 41 (2), 160-175.

Pangestu, M. E. (2015).The new economy and development: An Indonesian perspective. Harold Mitchell Development Policy Lecture. Canberra: Australian National University.

Salahudin Anas. (2011). Filsafat Pendidikan. Bandung: Pustaka Setia.
Smircich, Linda. (1983). Concept of Culture and Organizational Analysis. Administrative Science Quarterly.

Suharto. (2012). Pendidikan Berbasis Masyarakat. Yogyakarta: LKIS.

Sutisna, Oteng. (1982). Administrasi Pendidikan, Dasar Teoritis untuk Praktek Profesional. Bandung: Angkasa.

Tilaar, H.A.R. (2000). Pradigma Baru Pendidikan Nasional. Jakarta: Rineka Cipta.

Yukl, Gary. (2005). Kepemimpinan dalam Organisasi. Edisi ke 7. Jakarta: Indeks. 